\title{
XBRL and Integrated Reporting: The Spanish Accounting Association Taxonomy approach
}

Javier Mora Gonzálbez. XBRL Spain. javier.mora@xbrl.org.es

María Mora Rodríguez. AtoS. Spain. maria.mora@atos.net

\begin{abstract}
Recently, the International Integrated Reporting Council (IIRC) developed a Discussion Paper (DP), offering initial proposals for the development of an International Integrated Reporting Framework, combining and connecting financial and non-financial information, including past and future information and outlining the next steps towards its creation and adoption. Among different aspects and elements of a future integrated report, the DP develops the idea of a report supported by XBRL (eXtensible Business Reporting Language). The aim of this article is to explain the proposal made to the IIRC by the Spanish Accounting and Business Administration Association (Asociación Española de Contabilidad y Administración de Empresas, AECA) of a taxonomy for integrated reporting. In that proposal, the Association made use of the most recent technical developments of XBRL, which are briefly discussed in the first part of the article.
\end{abstract}

Keywords: XBRL, dimensions, formulae, financial information, integrated reporting.

\section{INTRODUCTION}

Recently, a new international forum has started to capture global attention: the International Integrated Reporting Committee or Council (IIRC), bringing together world leaders from the corporate, investment, accounting, securities, regulatory, academic, civil society and standard-setting sectors to develop a new approach to reporting. According to their own description, the approach of Integrated Reporting, will meet the needs of the 21 st century. It builds on the 
foundations of financial, management commentary, governance and remuneration, and sustainability reporting in a way that reflects their interdependence (IIRC, 2011). After many separate financial and sustainability efforts, at both national and international levels, this is the first time an international organization has aimed to play the role of systematizing corporate reporting, facing several issues like:

- the massive amount of organizational information, both audited and unaudited,

- the lack of connection between financial and sustainability publications,

- the inefficiencies of a PDF-based format for reports delivery.

As the aim of the IIRC is to provide guidelines for companies to prepare efficient, comprehensive and interoperable reports, they announce in their Discussion Paper the need for XBRL-supported developments. The aim of XBRL is exactly to improve the communication of financial and business information, allowing a seamless flow of data across computers and thus facilitating the sharing of data by the users (Valentinetti and Rea, 2011). XBRL is preferred as standard format by regulators, but also by companies that use it on a voluntary basis (Bonsón et al., 2009) and it is perceived today as a consolidated digital language with a growing impact in the academic and professional press since 1998 (Roohani, 2010). The aim of this work is to provide insights on the role of XBRL in such a task, reviewing also specific successful implementation cases from the European financial and supervisory community, given a new set of technical standards available, which increases the efficiency of XBRL reporting for both financial and non-financial information. XBRL, which will presumably have an impact on the accessibility of financial reports, easier regulatory compliance, enhanced availability of financial reports, facilitation of continuous reporting, and improved efficiency in investment and business decision-making in the near future (Baldwin and Trinkle, 2011) is going to play a relevant role in the future of integrated reporting.

\section{THE EVOLUTION OF REPORTING: COMPLEX REPORTS}

In 2005, the Committee of European Banking Supervisors (CEBS) ${ }^{1}$ started a convergence project called COmmon REPorting or COREP, in order to provide a

\footnotetext{
${ }^{1}$ Today formalized in the European Banking Authority or EBA.
} 
reusable data structure for the 27 EU banking supervisors regarding solvency control of financial institutions and investment firms. XBRL emerged as the most widely known and technically tested digital standard to support this new environment, but XBRL, in 2005, was prepared only to represent a 1-dimensional table as a balance sheet, with a column of labels and several columns for real data, one for each time period. COREP is about solvency reporting. Soon after, a parallel initiative arose, FINREP, to ensure homogeneous financial reporting for the banking sector according to the International Financial Reporting Standards plus specific supervisory requirements. Both initiatives joined to form the Eurofiling project. Clearly, to face this Eurofiling project, XBRL had to evolve, as reported by Boixo and Flores (2005), to ensure both European reporting comparability and respect at the same time for national specifications. It was the starting point of a new era for XBRL: new specifications to adapt the standard to the more demanding reporting requirements worldwide, as shown in Table 1.

\begin{tabular}{|l|l|l|}
\hline Level & Former status & New status \\
\hline General architecture & Intuitive & Formalized with Data Point Model \\
\hline Taxonomy & Definition Linkbase & Dimensions \\
\hline & Calculation Linkbase & Formulae Linkbase \\
\hline & Presentation Linkbase & Table Linkbase \\
\hline Instance & XML coded, machine-readable & iXBRL, HTML-friendly view \\
\hline
\end{tabular}

Table 1. New protocols and standards in XBRL projects

\section{NEW SPECIFICATIONS FROM THE XBRL COMMUNITY}

$\mathrm{XBRL}$ evolved over time as a response to corporate and regulatory challenges. As a result, new specifications have been developed. The first one of these described in this article, Data Points Model (DPM) or Data Points Modelling, is a first attempt to involve domain experts in IT architecture developments, by means of .xls matrices or similar resources, in order to start formalizing all the requirements of the new reporting and regulatory framework. References for this initiative can be found in working drafts and documentations of the COREP and other Eurofiling projects. The other advances, dimensions, tables, formulae and iXBRL, represent the way in which the XBRL 2.1 Specification has been extended to cover real business complexities, and each one of these corresponds to specific recommendations published by XBRL International. The use of the most advanced and rigorous standards in taxonomy development will help to a better 
assurance of future XBRL reports, as pointed out by many authors (Boritz and No 2003; Cohen et al. 2003; Lymer and Debreceny 2003; Boritz and No 2008; Plumlee and Plumlee 2008; Srivastava and Kogan 2009).

\subsection{Data points model (DPM)}

DPM is a form of representation of information requirements by identification of reportable information as data points that have a specified nature and can be characterized using consistently applied breakdowns. This approach has been developed for the purposes of the Eurofiling project (2011a). A data point or cell, as a financial concept, is characterized by defining its basic financial meaning (nature) and specifying information on the breakdowns (Eurofiling, 2011b) in which it is described in different tables or paragraphs of the documentation. An outcome of this process is a complete set of data points that are required to be reported. It explicitly describes all characteristics and allows relations to be identified between data points located in different tables or paragraphs of documentation. DPM as a data model introduces the initial distinction into primary items (basic financial meaning) and dimensions (breakdown) and differentiates the primary items based on the period type property (stocks/flows). Application of the DPM on the formal representation of information requirements (initial conceptual taxonomy) may assume some merging of basic financial meaning with some breakdowns (i.e. primary items are defined as a concatenation of the nature of a financial term with components of a breakdown). This merging must be applied consistently with regard to the nature of a financial concept and the breakdown. Among key points of DPM, it is possible to emphasize that:

- templates, usually .xls files prepared by domain experts, are the starting point,

- $\quad$ every piece of data is analyzed and its properties identified,

- properties/values are arranged as hierarchical trees, in what is called a normalized model,

- properties that are very specific to a particular item can be merged together (de-normalization),

- properties that are common to the model considered as a whole should remain as individual entities.

By means of this protocol, it is possible to model, in a rigorous manner, the way in which business concepts produce values and properties in a digital environment 
which concepts are related to which dimensions, and which relationships are prohibited. In this context, additional definitions of dimensions arise, as explained by the Bank of Spain (2010) (Table 2).

\begin{tabular}{|l|l|}
\hline $\begin{array}{l}\text { FAMILY OF } \\
\text { DIMENSIONS }\end{array}$ & $\begin{array}{l}\text { " Business/User point of view: Group of "domains/dimensions" that have a similar function in the } \\
\text { model (e.g. "Main category "is a family of dimensions of different domains: "Assets", "Liabilities", } \\
\text { etc.). } \\
\text { - These groups simplify the understanding of the data model from a business/user point of view. }\end{array}$ \\
\hline $\begin{array}{l}\text { KEY } \\
\text { DIMENSIONS }\end{array}$ & $\begin{array}{l}\text { - Dimensions that must be fulfilled for all data points (cells) of a reporting framework (e.g. "Main } \\
\text { category" and "Amount type"), even though the value to be reported could be "Not } \\
\text { specified"/"Not applicable". }\end{array}$ \\
\hline $\begin{array}{l}\text { OTHER } \\
\text { DIMENSIONS }\end{array}$ & $\begin{array}{l}\text { - Dimensions that must be fulfilled for those data points (cells) for which they are necessary for } \\
\text { identifying specific content, but not for the rest of the data points (e.g, "Remaining maturity" } \\
\text { must be included only in the data points (cells) with data on loans for which the remaining } \\
\text { maturity is one of their attributes). }\end{array}$ \\
\hline
\end{tabular}

Table 2. DPM in the XBRL projects by the Bank of Spain

\subsection{Dimensions}

XBRL Dimensions 1.0 (XBRL, 2011a) is a way to represent multi-dimensional data in XBRL, and it is similar in concept to Spreadsheet Pivot Tables ${ }^{2}$, once they have been designed by means of the DPM methodology. XBRL Dimensions 1.0 is a module of XBRL 2.1 Specification and it achieved Public Recommendation status in 2005. A new edition of the Dimensions 1.0 Specification with errata corrections was issued on 7 September 2009. The Dimension 1.0 Specification enriches the rules and procedures for constructing dimensional taxonomies and instance documents. It supports the use of XBRL taxonomy Linkbases to define additional, structured contextual information for business facts. Each piece of contextual information is referred to as a "dimension." The base XBRL Specification essentially defines three dimensions: reporting period, reporting entity (i.e. a company or a division thereof), and a loosely-defined reporting scenario, originally intended to distinguish between actual vs. projected facts. Some analysts have opined that dimensions complicate XBRL, but the reality is that the use of dimensions in non-forms-based reporting simplifies tagging and taxonomies (i.e., it reduces the number of elements). Dimensional metadata was not created ad hoc for XBRL reporting purposes. XBRL standardizes the

2 In data processing, a pivot table is a data summarization tool found in data visualization programs such as spreadsheets or business intelligence software. Among other functions, pivottable tools can automatically sort, count, total or give the average of the data stored in one table or spreadsheet. Microsoft Corporation has trademarked the specific form PivotTable. 
representation of only two dimensions: the time dimension and the entitycompany dimension.

Many reporting purposes, both internal and external to organizations, require multiple dimensions. What the XBRL 2.1 Specification created was the principles for this specification to exist while defining two open elements in the context of XBRL instance documents: the segment and scenario elements. XBRL Dimension 1.0 defines the syntax of elements that may occur in the segment and scenario elements and defines standard arcs that define the valid content of those elements. That content should be validated by dimensional XBRL processors, and standard errors are raised if the XBRL instance does not conform with the multidimensional model defined in the taxonomy. XBRL Dimension 1.0 adds a necessary, and a very powerful, feature to XBRL: the ability to articulate, in a global standard way, what is typically seen as "drill down" information for a reporting entity. Having this information expressed as a global standard facilitates the exchange of this information between different software applications, rather than locking users into one software application whose information cannot be exchanged effectively with others without human intervention.

Taxonomies using XBRL Dimensions can define new dimensions, specify the valid values ("domains") for dimensions, designate which dimensions apply to which business concepts through mechanisms called "hypercubes", and relate other taxonomy metadata (labels, presentation information, etc.) to dimensions. Very relevant taxonomies, like the US GAAP Financial Reporting Taxonomy (SEC, 2009) or IFRS Taxonomy 2011, use XBRL Dimensions. To illustrate which kind of reporting problem is solved with the XBRL dimensional architecture, it is possible to conceive a company whose revenue comes from selling several products, which are sold in several countries (Table 3). Additionally, that company applies a complex system of discounts, and it operates by means of different subsidiaries which it creates ad hoc for a business and deletes later. So, for that company its revenue can be a single figure in Euros, but it can also be broken down by means of an $n x m x o$ matrix. We can then call primary items those elements to which the sale is directly related (n product types). This information can then be disaggregated according to two explicit dimensions ( $\mathrm{m}$ countries or o discount types). Additionally, there is an open or implicit dimension, which is the code of the exact subsidiary for which the sales 
report is created. The difference here is that we do not have a priori a fixed set of subsidiaries, and their code must be reported every time. This is the type of complexity which is solved using the XBRL dimensional specification, where it is possible to report in an XBRL instance a context element for each Cartesian product cell, so that every real value can be perfectly identified with its coordinates by means of the context ID related to it in the XBRL instance. It is in the Taxonomy where permitted and prohibited products are defined.

\begin{tabular}{|l|l|l|l|}
\hline & Subsidiary code: & $\ldots$ & \\
\hline & Country 1 & $\ldots$ & Country $\mathrm{m}$ \\
\hline Product 1 & & & \\
\hline Product 2 & -prohibited match - & & \\
\hline$\ldots$ & & & \\
\hline Product $\mathrm{n}$ & & & \\
\hline & Subsidiary code: & $\ldots$ & \\
\hline & Discount 1 & $\ldots$ & Discount $\mathrm{o}$ \\
\hline Product 1 & & & \\
\hline$\ldots$ & & & \\
\hline Product $\mathrm{n}$ & & & \\
\hline
\end{tabular}

Table 3. Example of multidimensional table as a common business case

\subsection{Formulae}

XBRL Formula 1.0 is also a module of the XBRL 2.1 Specification (XBRL, 2011b). This module allows the users to create analytics and to impose sophisticated validation constraints, with a full set of mathematical functions to produce exactly what is needed. XBRL Formula 1.0 achieved Public Recommendation status on 22 June 2009. Formula Specification 1.0 defines a syntax that can be used to document the rules for deriving new XBRL facts from information obtained from XBRL instances. The transformation rules expressed in a formula serve two purposes. First, they constitute additional documentation about the facts being reported in XBRL instances. Second, formulae can be processed to produce XBRL facts. When evaluated successfully against an input XBRL instance, formulae produce new XBRL facts. Formulae can also be understood as an extension of classical XBRL fact validation. XBRL 2.1 Specification provides different types of validation for instance documents: Basic XBRL validation, XML Schema validation, Calculation Linkbase, XBRL Dimensions, and the final user can produce different outputs using the raw data 
contained in the initial XBRL report (Figure 1). But this is not enough in most cases such as basic arithmetic operations (e.g. product, division), arithmetic comparisons (e.g. item A must be equal to item B), and checks for the presence of elements. Finally, following XBRL 2.1 Specification solely, derivation of new facts from existing ones is not possible. The general process for a formula is to apply it against a single input XBRL instance, to produce a single XBRL fact in an output XBRL instance. An output XBRL instance is an XBRL instance that is generated by an XBRL formula processor, and contains, possibly along with other information, facts produced by evaluation of formulae. Formulae have been designed to be general enough to support a wide range of specific usage patterns, such as validation of XBRL instances against a set of business rules (Figure 2).

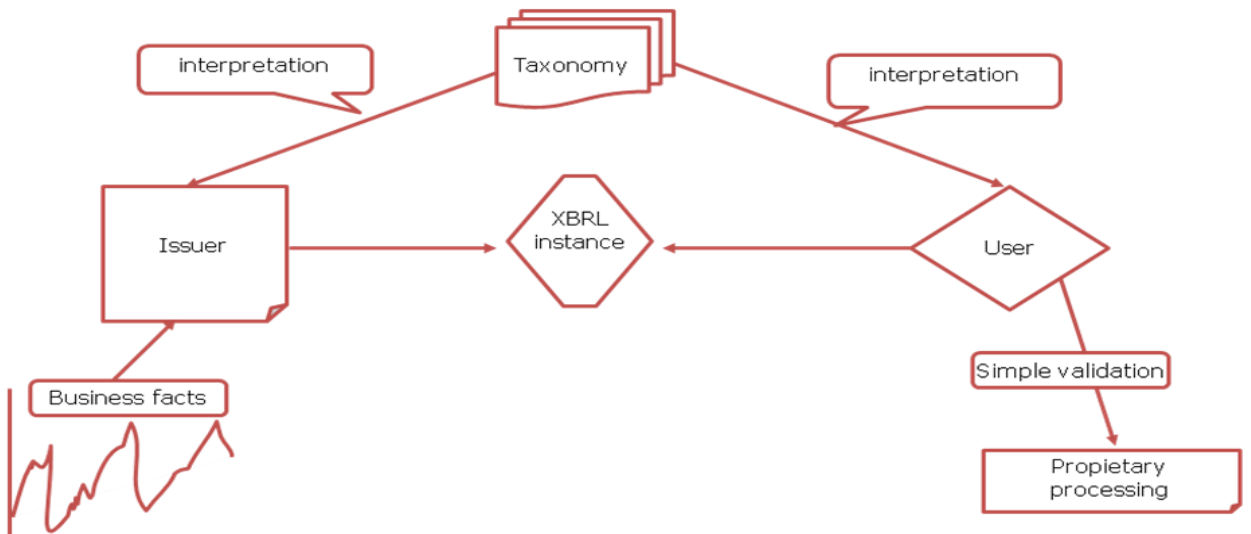

Figure 1. XBRL 2.1.

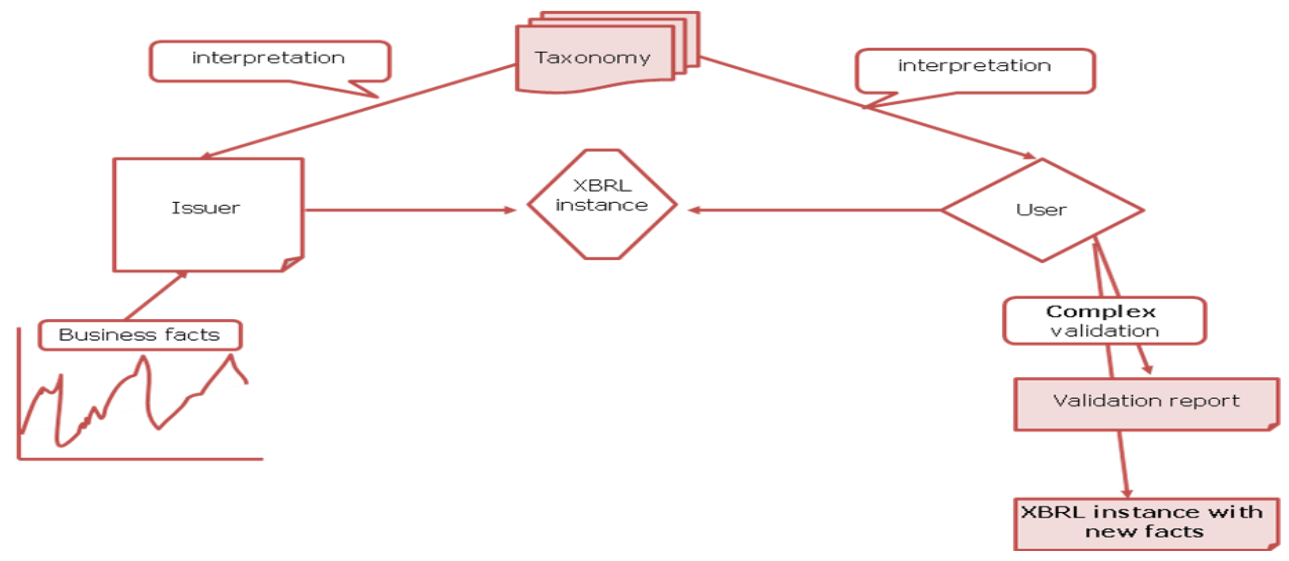

Figure 2. Formulae 
Among the benefits of using formulae it is possible to highlight that:

- it is a powerful and flexible solution,

- it provides better software maintainability,

- it makes taxonomies even more reusable between different actors,

- data is available sooner and with improved quality level and

- commercial tools are available to use it.

Several regulators like the Bank of Spain and the Bank of France, along with commercial banks and other financial actors, are already collecting large amounts of financial and performance information using formulae to impose complex validation rules to both improve the quality of data that arrives and automate the promulgation of those rules so that they can be executed in a distributed manner. Professional analysts, broker/dealers, hedge and mutual funds as well as a wide range of financial infomediaries can use the formula specification to define proprietary analytics on raw performance information.

\subsection{Table Linkbase}

Regarding Table Linkbase, it is important to note that standard application of the XBRL 2.1 Presentation Link is not sufficient to reflect the layout of information requirements that is expressed by tables defined in COREP 2012 and FINREP 2012, based on Dimensions and DPM. Table Linkbase is the way to represent COREP 2012 and FINREP 2012 templates through XBRL tables. XBRL tables define subsets of the facts and fact-related information, defined by a Discoverable Taxonomy Set (DTS), and they specify representation of those facts in a Cartesian coordinate system. XBRL Tables can be used alone, by tools and consuming applications, or as part of containers in XBRL documents that generate complete reports. Table concepts are defined by abstract concepts and concrete concepts, in a manner that provides a base for extension specifications. XBRL tables specify the semantics and syntax of hierarchical representations of facts that instantiate the concepts in XBRL taxonomies. These hierarchies are one of the basic building blocks of the specification, but also constitute by themselves a vehicle to communicate the meaning of those reporting concepts in a similar approach to 
that of the Presentation Linkbase, but enhanced to cover multidimensional information and more complex models. In other words, Table Linkbase represents the evolution of the classical XBRL 2.1 Presentation Link to allow visualization of Dimensional XBRL instances, where iXBRL was unable to (Figure 3).

\begin{tabular}{|l|l|l|l|}
\hline & Subsidiary code: & $\ldots$ & \\
\hline & Country 1 & $\ldots$ & Country $\mathrm{m}$ \\
\hline Product 1 & & & \\
\hline Product 2 & -prohibited match- & & \\
\hline$\ldots$ & & & \\
\hline Product $\mathrm{n}$ & & & \\
\hline & Subsidiary code: & $\ldots$ & \\
\hline & Discount 1 & $\ldots$ & Discount $\mathrm{o}$ \\
\hline Product 1 & & & \\
\hline Product 2 & & & \\
\hline$\ldots$ & & & \\
\hline Product $\mathrm{n}$ & & &
\end{tabular}

Figure 3. Correspondence between dimensional definition and Table Linkbase

Key points of Table Linkbase are that it:

- fills the gap between the model and the visualization in the XBRL instance,

- improves the understanding of the model,

- provides mapping information from tables to the model for filers,

- improves the way other XBRL standards operate, for instance, formulae error messages can be displayed in a more efficient manner, and

- allows the partition of data into subsets; in general, it improves the ability of software and databases to process XBRL instances. 


\subsection{Inline XBRL (iXBRL)}

Inline XBRL 1.0 (iXBRL) is the way to visually represent an XBRL report (XBRL, 2011c). It consists in the fact that the metadata of an XBRL instance are embedded within on a well-formed HTML or XHTML document. It responds to the need to have a direct rendering solution for an XBRL report, so that when an instance is open in any computer or mobile device it can be directly understood by humans, along with all its process-ability by applications. So, Inline supposes the solution of publishing an XBRL report. Among the benefits of using $i X B R L$, it is possible to highlight that:

- an Inline XBRL report may be opened and viewed with a standard web browser, because it is HTML, and the same document is suitable for processing with an XBRL processor, because it contains XBRL metadata,

- visual data are prepared for internal consolidation and other complex purposes with intensive human intervention,

- comparative corporate information can be almost immediately published on a web-page.

Regarding its usage, it is relevant to cite that, in the UK, from 1st April 2011, for any accounting period ending after 31st March, HM Revenue and Customs requires businesses to submit their report and accounts and tax computations in iXBRL format when making their Corporation Tax return.

Despite its advances, several problems of compatibility were identified when XBRL Working Groups tried to combine Dimensions and XXBL. This is one of the main reasons why the XBRL Consortium developed the third standard already mentioned, Table Linkbase (XBRL, 2011d), at the taxonomy level. Both standards can be combined, as the complex visual structure can be defined at the taxonomy level and then represented in visual format by means of iXBRL.

\section{XBRL TAXONOMY FOR INTEGRATED REPORTING}

The new specifications discussed above were incorporated in the design of a new version of existing taxonomies in the financial arena. Additionally, they are present in a new taxonomy for financial and non-financial information, which is 
for Corporate Social Responsibility reporting purposes. They were especially taken into account when developing a taxonomy which combines financial and non-financial information: the Integrated Scoreboard for Financial, Environmental, Social and corporate Governance reporting (IS-FESG) by the Spanish Accounting and Business Administration Association (Asociación Española de Contabilidad y Administración de Empresas, AECA). AECA has been the first global institution to promote the use of the XBRL standard for the production and submission of Corporate Social Responsibility information on the Internet, with internationally acknowledged taxonomies and an online repository with real XBRL instances created by both listed corporations and SMEs (AECA, 2011). As was mentioned earlier, the aim of the IIRC is to create a globally accepted integrated reporting framework which brings together financial, environmental, social and governance information in a clear, concise, consistent and comparable format. The aim is to help with the development of more comprehensive and comprehensible information about organizations, prospective as well as retrospective, to meet the needs of a more sustainable, global economy. For that, one of the most important items to be incorporated into the reporting framework is the set of International Financial Reporting Standards, issued also in XBRL format by the IFRS Foundation (IFRS Foundation, 2011). Both IFRS and XBRL are intended to standardize financial reporting in order to promote transparency and to improve the quality and comparability of business information; therefore the two form a perfect partnership. Also, the US GAAP and the Spanish GAAP are considered, as both are under strong convergence with the IFRS.

With previous international experience of AECA also applying XBRL to CSR reports, there exists a great opportunity to develop this integrated reporting framework also in the best digital format, free of royalties and using open technologies. The aim of the IIRC is to focus initially on listed companies, for which IFRS are compulsory in the EU at the group level. But, while this scenario is becoming a reality, first for listed companies, there is a big concern in Europe regarding the competitive situation of small and medium sized companies (SMEs) which generate a major stake of welfare and employment.

With the aim of providing a realistic first step in the proposed direction, and to contribute with a scenario in which SMEs could gradually acquire the skills that 
will be needed in the new framework, the aim of AECA is to perform an international XBRL project that will provide an integrated reporting toolkit for both listed companies and SMEs, based on:

- the availability of International Financial Reporting Standards for both listed and small and medium-sized companies, along with national equivalent XBRL taxonomies for financial data,

- the existence of an internationally acknowledged framework of Corporate Social Responsibility for both listed companies and SMEs proposed by AECA, and acknowledged by XBRL International,

- the advantages of XBRL and open source applications to promote integrated reporting and an efficient validation, reutilization, rendering, sharing and analysis from corporate data.

This contribution will be divided into two parts: a conceptual proposal for KPIs (financial, social, environmental, corporate governance and remuneration Key Performance Indicators), a proposal that will be made public in 2012; and on the other hand, being firstly applied to that, a tested XBRL architecture, by means of an Integrated Scoreboard Taxonomy, or IS Taxonomy, that will also be available for use in the forthcoming IR XBRL Taxonomy, if so required by the IIRC. Concerning the proposal for KPIs, it is worth explaining that, in an integrated report, there will be three different layers of indicators. In fact, for a single KPI, it is possible to determine if it refers to flow or stock data, if it is historical or prospective, if it contains quantitative or qualitative data, if it is reported by a company or about a company but by any of its stakeholders. Of course, it is possible to divide KPIs by nature as mentioned (FESG breakdown, or the popular triplet, profit, people and planet, to which could be added a fourth: pilots, to refer to corporate governance issues). Paying attention to this last FESG breakdown, and if we go up in complexity, then it is possible to present:

- basic indicators: they will be expressed in absolute value, and will belong to the financial, social, environmental or corporate governance arenas, 
- composed indicators: will also belong to any of the four specific areas, but will be expressed in relative terms, once divided by a reference of its area, (i.e., revenue for financial indicators),

- complex indicators: will put in relation drivers from different areas (i.e., financial vs. environmental ones) (Figure 4). .

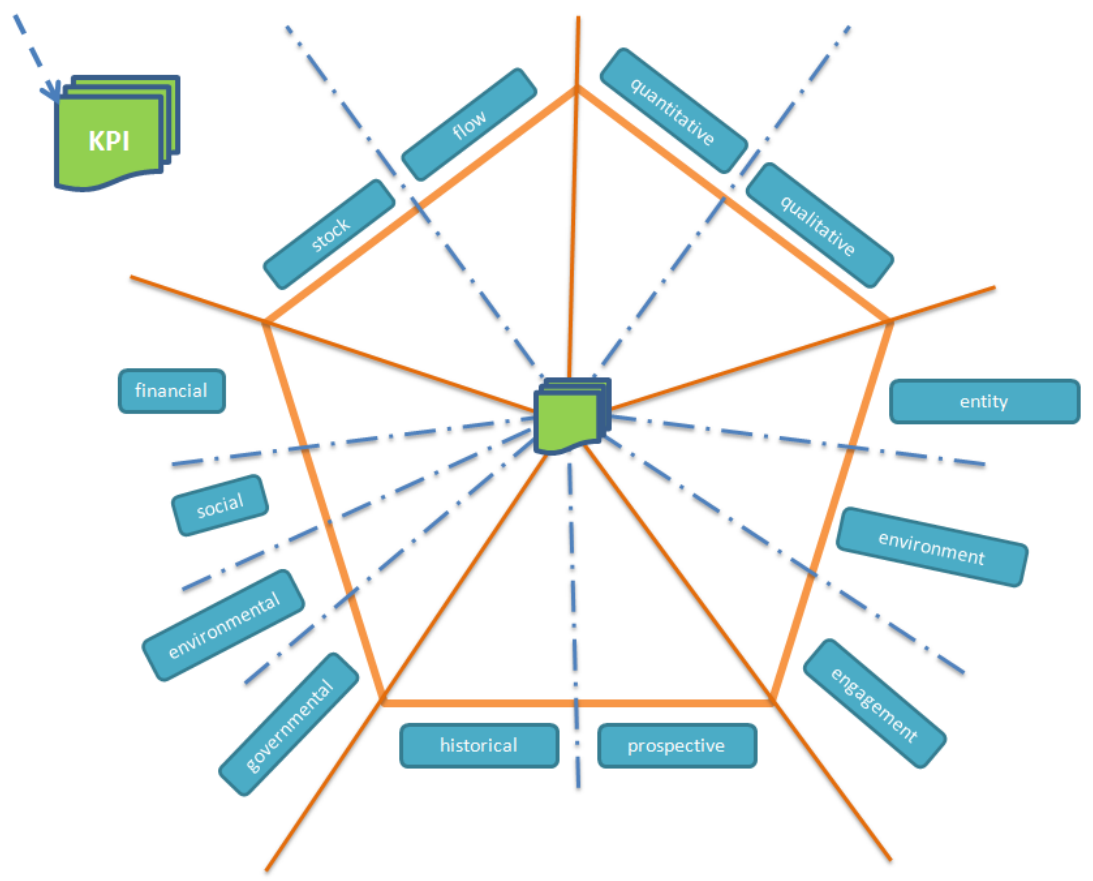

Figure 4. Hierarchy of indicators in an integrated report
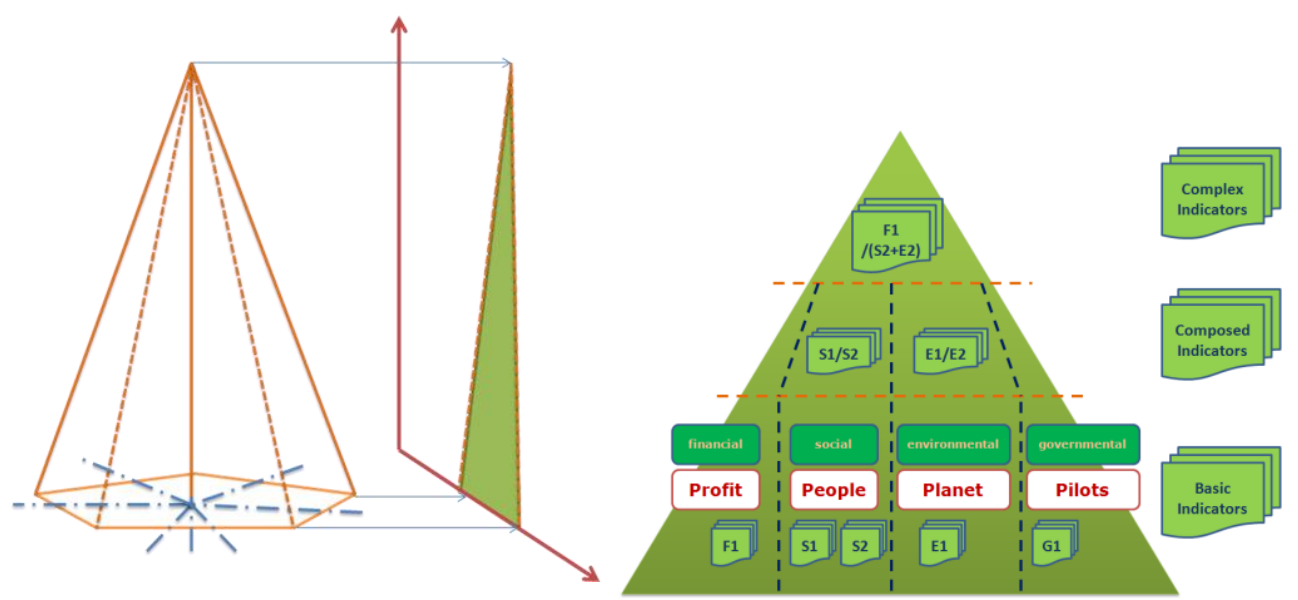

Figure 4. Hierarchy of indicators in an integrated report (continued) 
To solve this challenge, and regarding the technical architecture, it is worth noting the role that both dimensions and formulae will play. Formulae will allow us to verify if the real facts reported by a given issuer will respect the complex indicator definition, and if these values are coherent with those reported for the composed and basic ones (Figure 5).

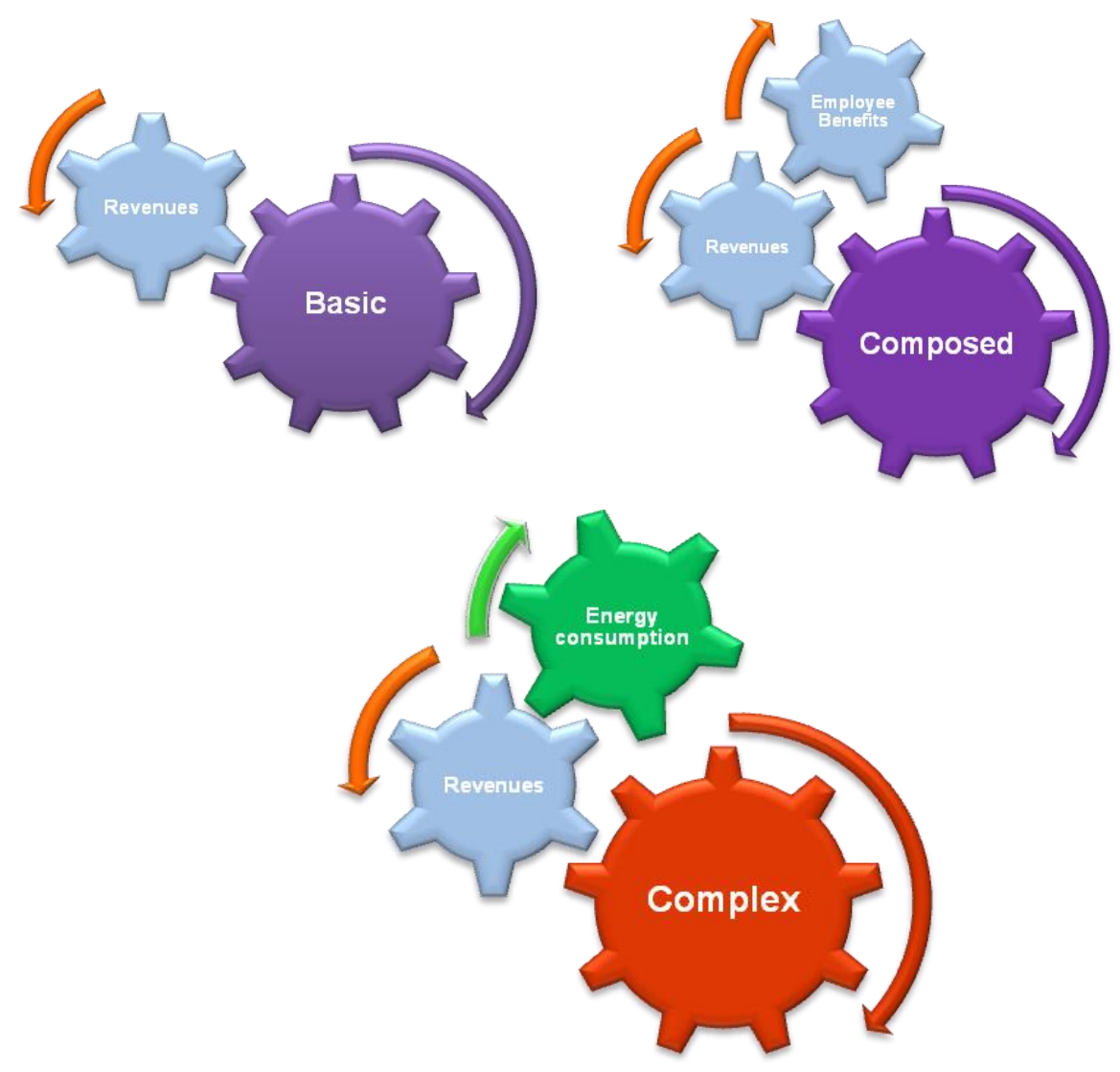

Figure 5. Hierarchy of indicators in an integrated report

By means of the dimensional definitions, the integrated report will provide multidimensional representation of the main company drivers, such as:

- KPI + strategic objectives: economic efficiency, energy consumption efficiency, emissions reduction, waste processing, increase in human and social capital and fair corporate governance. Each of these strategic 
objectives can be quantified by means of an expected value of a correspondent KPI or by means of a favourable trend in successive KPI values period after period.

- Basic frames for KPIs, ordered by nature as:

- Financial,

- Environmental,

- Social,

- Corporate Governance ones,

- Composed Complex Integrated Frame: where the values of composed and complex indicators are reported.

The general architecture for KPIs can be observed in Figure 7c.

- KRI (Key Risk Indicators): ordered by nature as described for KPIs, plus classified by means of a breakdown of loss type. Specifically, a KRI is a type of loss which is recorded in order to generate a database that allows companies to assess their risk levels.

Although KPIs are defined in the taxonomy to a certain level, KRIs are entirely to be decided by each company. Initially, it is not expected that companies will be seen reporting KRIs to the public, as this information is traditionally reserved for the supervisory authorities, but, when designing the IS-FESG taxonomy, the Working Group decided to incorporate them in order to fulfill all the DP requirements.

Thanks to the dimensional definitions, it is possible to represent the different possibilities to combine dimensional domains (Figure 6). In the case of the four basic KPI frames, the representation of the dimension is defined by:

- Performance measuring indicators: reported, expected, fulfillment, change. Expected values represent prospective information as required by the IIRC DP, along with the fact that they constitute a commitment for the company to apply policies and actions to reach these expected values in their KPIs. Fulfillment (quotient between reported and expected values) is a simple but powerful tool to evaluate deviations. When companies do not declare 
expected values, the change rates allow users to check if the company is successfully reaching its strategic objectives.

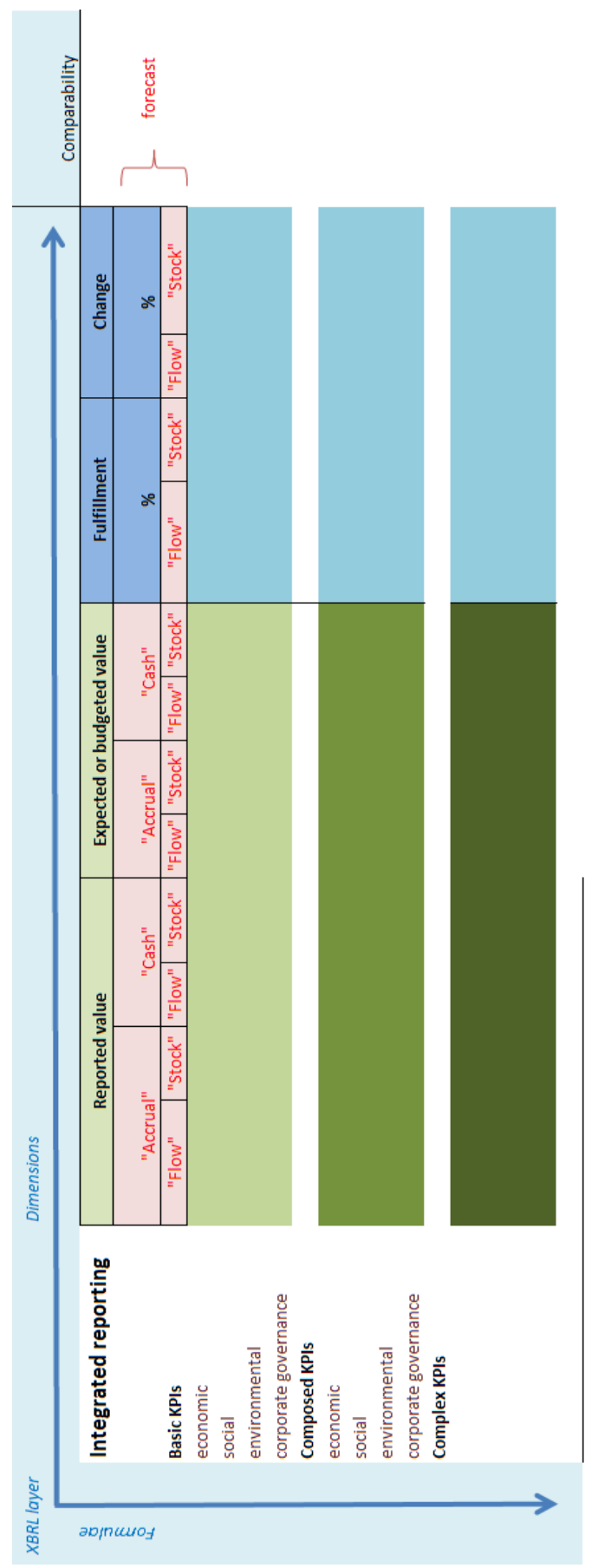


- Coverage context indicators: flow, stock.

- FESG indicators: financial, environmental, social, corporate governance.

- Definition value: data, not available, not applicable.

Comparability is enabled in two different ways:

- using composed and complex indicators, users can compare two or more companies,

- using fulfillment and change, it is possible to compare a company with itself over time.

The dimensional representation is based on the Data Point Model (DPM), described above. Conceptually, the complexity is increased when the composed and complex indicators need to be defined (Figure 7). They are expressed in relative terms, meaning that specific relationships between the same area (composed) or different areas (complex) appear. Screenshots are provided by Fujitsu Interstage XWand software (Fujitsu, 2011) with several points highlighted by the authors.

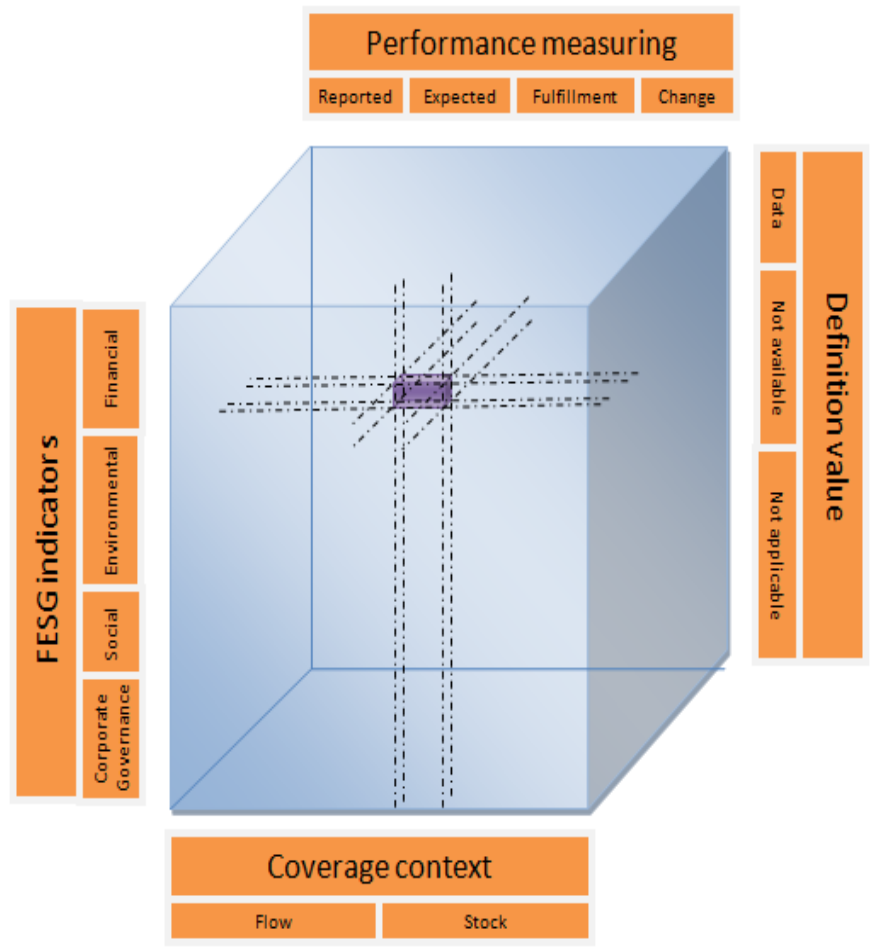

Figure 7. Integrated Scoreboard dimensional structure 
Additionally, thanks to the formulae implementation, a real integration of indicators can be outlined, since the formulae specification offers the tools to define business rules in the XBRL taxonomy, adding the validation capacity in the instance. This capacity is essential for the integrated reporting means. The possibility to integrate all these indicators using mathematical rules is the real essence of the integration. A total of 33 formulae are included, divided into three categories: basic, composed and complex. Figure 8 presents a visualization of how Dimensions operate, to allow the reporting of a composed indicator, by coordinates of some of the basic KPIs with another KPI which is used as a pivot (e.g. Suppliers' expenses / Revenue). This Table also contains complex indicators if financial and environmental indicators are combined (e.g. Energy consumption / Revenue). In most cases, the value of one of these composed or complex indicators will not be significant itself, but its evolution will be, as a direct way to check the achievement of strategic objectives, via trend analysis or via fulfillment analysis -when the outcomes are published.

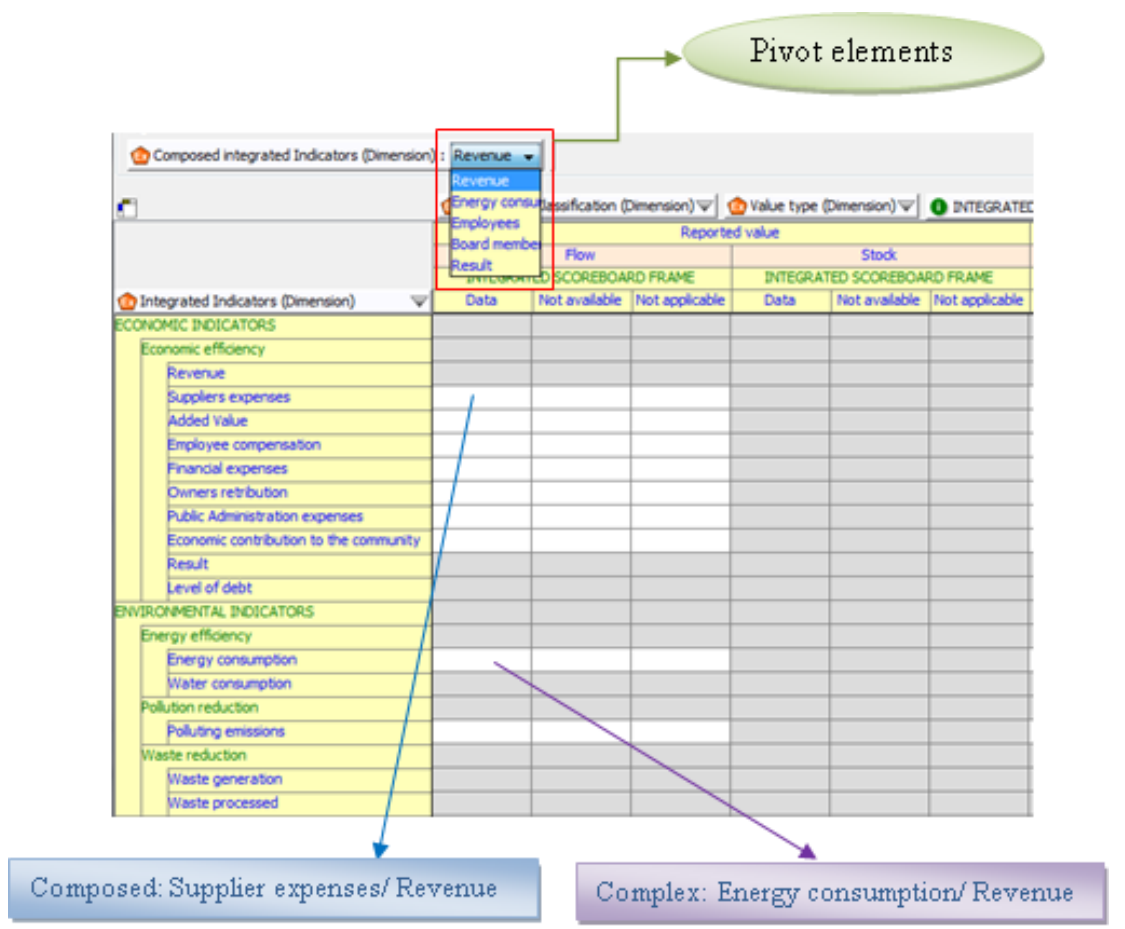

Figure 8. Generation of composed and complex indicators 
Formulae allow the verification that this relative calculation is coherent with the basic absolute values reported in the basic frames (Figure 9):

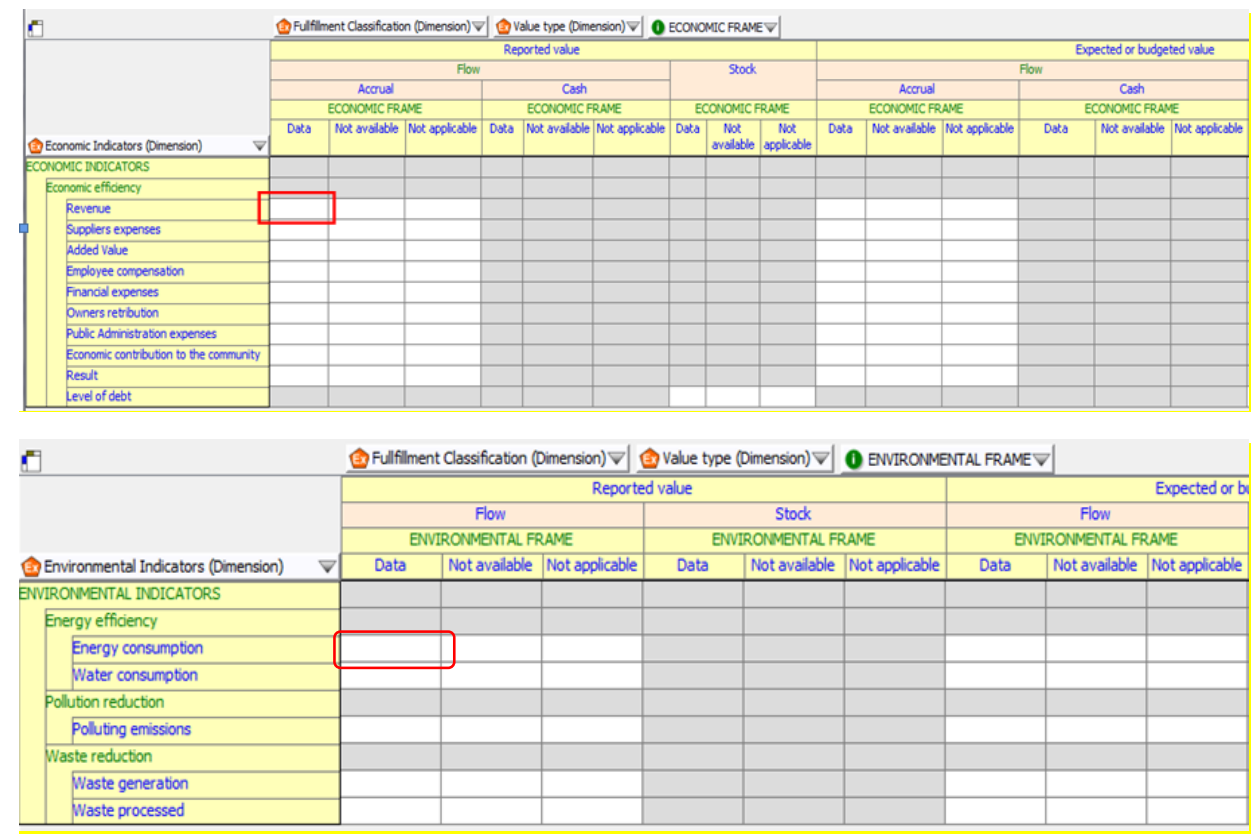

Figure 9. Basic financial and environmental frames with facts in absolute terms

This proposed IS-FESG taxonomy architecture is clearly devoted to promoting taxonomy extensions, for a double purpose:

- from the issuer's perspective: there is an interesting possibility to extend the taxonomy, by adding new columns (dimensions) or validation rules (formulae), in order to increase the complexity of publishable reports, and to adapt to the behaviours that both stakeholders and entity managers will be required to monitor,

- from the analyst's perspective: it is possible to use additional dimensional relationships and/or formulae to perform specific treatments on entity data, at the taxonomy layer, without the need for software re-programming.

Regarding the use of iXBRL in this IS taxonomy, there will be available, for every instance, a friendly visual version, suitable for HTML browsers like Internet Explorer, Mozilla Firefox or Google Chrome. The report regarding the KPIs, once completed and visualized, will have the columns and properties reflected in Figure 10. 


\section{KPIs frame}

\begin{tabular}{|l}
\hline Financial Indicators \\
\hline Economic efficiency \\
\hline .
\end{tabular}

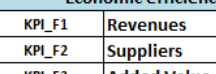

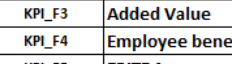

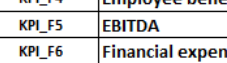

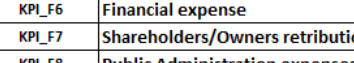

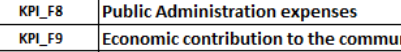

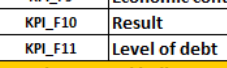

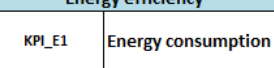

KL!E2 Water consump

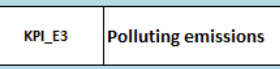

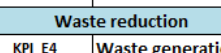

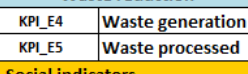

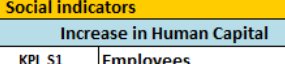

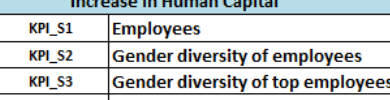

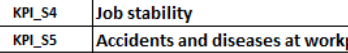

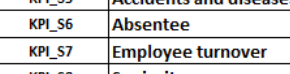

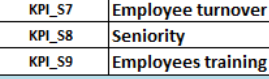

kpl_sio Non-compliance with legal regulation concerning customers num

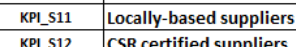

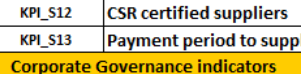

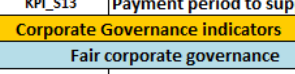

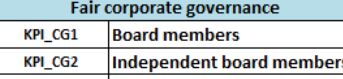

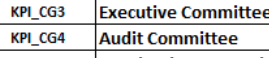

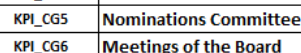

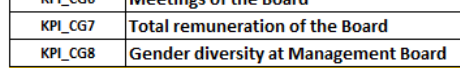

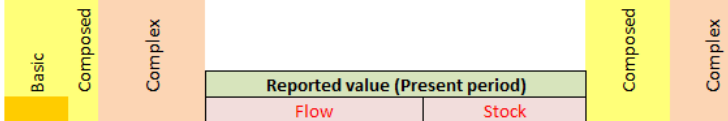

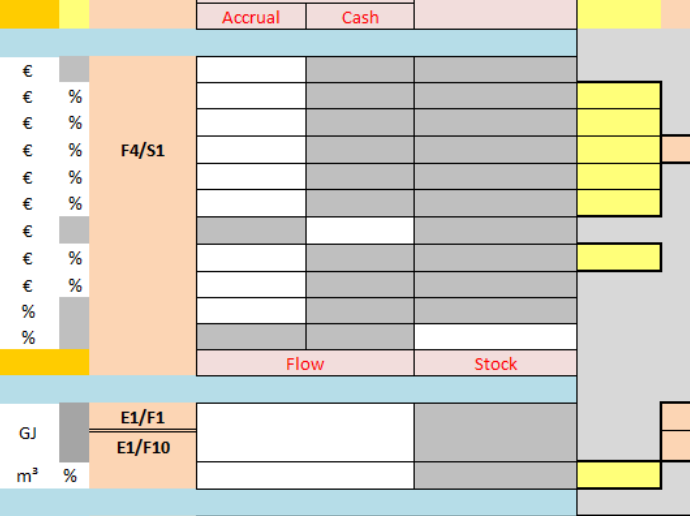

6E1 \% $\frac{B 3 / F 1}{B / F 10}$ ${ }_{t}^{t} \%$

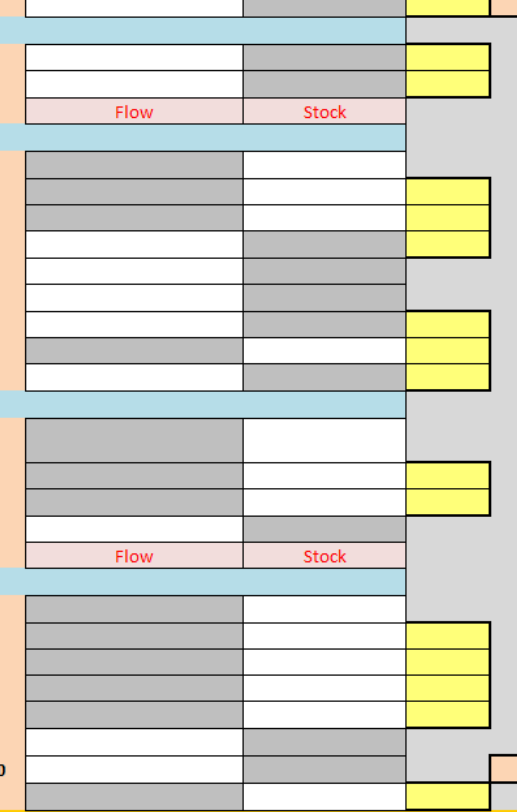

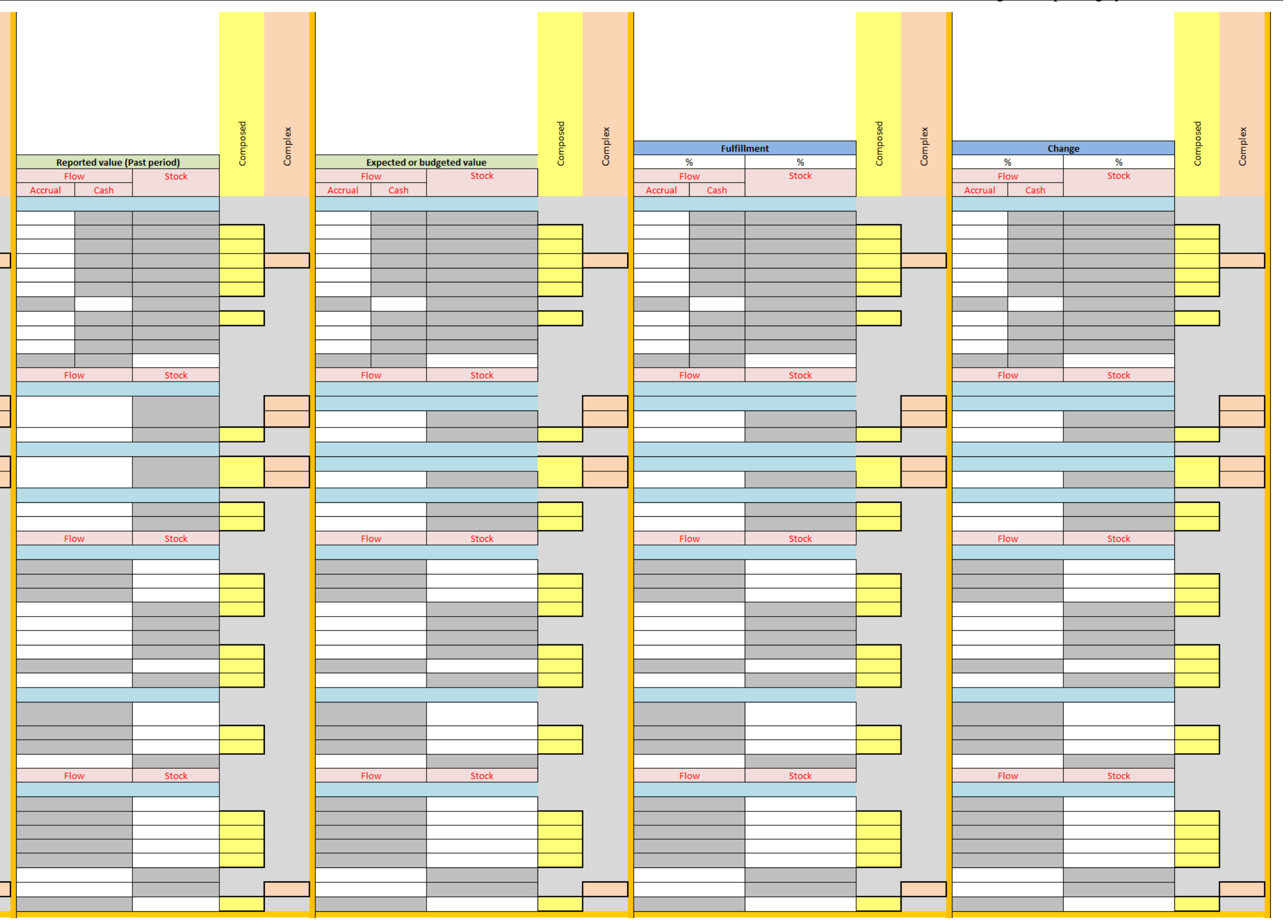

Figure 10. Integrated report. KPI frame 
Regarding the potential impact and implementation of the IS-FESG taxonomy, it is relevant to note that it is expected to receive acknowledgement status from XBRL International, and that AECA will elaborate test cases with real information from the top five Spanish listed companies taking part in the IIRC 2012 Pilot Program (Table 4).

\begin{tabular}{|c|c|c|}
\hline Company & Country & Industry \\
\hline AB Volvo - Volvo Group & Sweden & Automobiles \\
\hline AEGON NV & Netherlands & Financial Services \\
\hline Akzo Nobel N.v. & Netherlands & Chemicals \\
\hline ARM Holdings plc & United Kingdom & Technology Hardware \& Equipment \\
\hline Association of Chartered Certified Accountants & United Kingdom & Accounting \\
\hline Atlantia S.p.A. & Italy & Industrial Transportation \\
\hline BAM Group & Netherlands & Construction and materials \\
\hline BBVA & Spain & Banks \\
\hline BWise b.v. & Netherlands & Support services \\
\hline Chartered Institute of Building, The & United Kingdom & Professional Organization \\
\hline Charted Institute of Management Accountants, The & United Kingdom & Accounting \\
\hline Cliffs Natural Resources & United States of Ameri & Industrial Mining \& Metals \\
\hline CLP Holdings Limited & China & Electricity \\
\hline CNDCEC & Italy & Accounting \\
\hline DANONE & France & Food Producers \\
\hline Deloitte LLP & United Kingdom & Accounting \\
\hline Deloitte Netherlands & Netherlands & Accounting \\
\hline Diesel \& Motor Engineering PLC & Sri Lanka & Industrial Engineering \\
\hline Edelman & United States of Ameri & Media \\
\hline ENAGAS, S.A & Spain & Gas, Water \& Multi-utilities \\
\hline EnBW Energie Baden-Württemberg AG & Germany & Electricity \\
\hline Enel S.p.A & Italy & Electricity \\
\hline eni S.p.A. & Italy & Oil \& Gas Producers \\
\hline Ernst \& Young Nederland LLP & Netherlands & Accounting \\
\hline Ernst \& Young ShinNihon LLC & Japan & Accounting \\
\hline Eskom Holdings SOC Limited & South Africa & Electricity \\
\hline Eureko (Achmea) & Netherlands & Insurance \\
\hline Flughafen München $\mathrm{GmbH}$ & Germany & Transportation Services \\
\hline Gold Fields & South Africa & Mining \\
\hline Grant Thornton UK LLP & United Kingdom & Accounting \\
\hline HSBC Holdings plc & United Kingdom & Banks \\
\hline Indra & Spain & Software \& Computer Services \\
\hline Industria de Diseño Textil, S.A. (Inditex) & Spain & General Retailers \\
\hline KPMG International & Switzerland & Accounting \\
\hline LeasePlan Corporation N.V. & Netherlands & Financial Services \\
\hline Marks and Spencer Group plc & United Kingdom & General Retailers \\
\hline MASISA S.A. & Chile & Forestry \& Paper \\
\hline mecu Limited & Australia & Banks \\
\hline Microsoft Corporation & United States of Ameri & Software \& Computer Services \\
\hline N.V. Luchthaven Schiphol & Netherlands & Transportation Services \\
\hline National Australia Bank Limited & Australia & Banks \\
\hline Natura & Brazil & Personal goods \\
\hline Novo Nordisk & Denmark & Pharmaceuticals \&Biotechnology \\
\hline PricewaterhouseCoopers N.V. & Netherlands & Accounting \\
\hline Prudential Financial, Inc. & United States of Ameri & Financial Services \\
\hline Randstad Holding N.V. & Netherlands & Support Services \\
\hline Rosneft & Russian Federation & Oil and Gas \\
\hline Sainsbury's & United Kingdom & Food retail \\
\hline SAP & Germany & Software \& Computer Services \\
\hline Showa Denki Co Ltd. & Japan & Household Goods \& Home Construction \\
\hline Solvay & Belgium & Chemicals \\
\hline State Nuclear Energy Corporation ROSATOM & Russian Federation & Utilities / Aerospace \& Defense \\
\hline Stockland & Australia & Real Estate Investment \& Services \\
\hline Takeda Pharmaceutical Company Limited & Japan & Pharmaceuticals \&Biotechnology \\
\hline Telefónica S.A. & Spain & Telecommunications \\
\hline Terna SpA & Italy & Electricity \\
\hline The Coca-Cola Company & United States of Ameri & Beverages \\
\hline
\end{tabular}

Table 4. Top global listed companies participants in 2012 IIRC Pilot Program 


\section{FINAL CONSIDERATIONS}

The most recent developments from the XBRL community, also with an increase in international presence (XBRL, 2011e), have made it possible to exploit the functionalities of the standard to its true potential. Both dimensions and formulae specifications are answers to business challenges and demonstrate how the XBRL consortium and jurisdictions are sensitive to corporate and regulatory needs worldwide.

With the urgent requirement for $\mathrm{EU}$ integration and along with the emergence of proposals such as those from the IIRC, XBRL will provide concrete and tested solutions for a more efficient reporting environment. The Spanish Accounting and Business Administration Association proposed to the IIRC a full XBRL taxonomy, using all the technical advances available. This proposal is expected to be tested by major Spanish and international companies during 2012 and 2013. Further research will be required following this study, in order to check potential implementation issues and avenues for the improvements of the specifications described here.

\section{ACKNOWLEDGEMENTS}

The authors would like to thank, for their contribution to this article, Enrique Bonsón (Editor at IJDAR and Professor at the University of Huelva), Francisco Flores (Iriarte College of Tourism and Management, Tenerife), José Luís Lizcano (General Manager of AECA, Madrid, and Director of this project) and Manuel Rejón (Independent CPA, Granada), who are also members of the AECA's Working Group which is developing, at the time of writing, the IS-FESG Taxonomy in collaboration with the IIRC and top listed companies in Spain.

This study has been carried out with the financial support of the Spanish National R\&D Plan through research project ECO2011-28267 (ECON-FEDER).

\section{REFERENCES}

AECA (2011): CSR-XBRL Repository. http $/ /$ aecareporting.com

BALDWIN, A.; TRINKLE, B. (2011): "The Impact of XBRL: A Delphi Investigation", The International Journal of Digital Accounting Research, vol. 11: 1-24. http://dx.doi.org/10.4192/1577-8517-v11_1 
BANK OF SPAIN (2010): "DPM for collecting data for BSI/MIR statistics using XBRL". http//bit.ly/AaNeAV

BOIXO, I.; FLORES, F. (2005): "New Technical and Normative Challenges for XBRL: Multidimensionality in the COREP Taxonomy", The International Journal of Digital Accounting Research, vol. 5: 79-104. http://dx.doi.org/10.4192/ 1577-8517-v5_3

BONSÓN, E.; CORTIJO, V.; ESCOBAR, T. (2009): "A Delphi Investigation to Explain the Voluntary Adoption of XBRL", The International Journal of Digital Accounting Research, vol. 9: 193-205. http//dx.doi.org/10.4192/1577-8517-v9_7

BORITZ, J.E.; NO, W.G. (2003): Assurance Reporting for XBRL: XARL (eXtensible Assurance Reporting Language). In S. Roohani (ed.) Trust and Data Assurances in Capital Markets: The Role of Technology Solutions. Bryant College: 17-31. http://www.xbrleducation.com/pubs/PWC_Book.pdf

BORITZ, J.E.; NO, W.G. (2008): "The SEC's XBRL Voluntary Filing Program on EDGAR: A Case for Quality Assurance", Current Issues in Auditing, vol. 2, n.2: A36-A50. http://dx.doi.org/10.2308/ciia.2008.2.2.A36

COHEN, E.E.; LAMBERTON, B.; ROOHANI, S. (2003): The Implications of Economic Theories for Data Level Assurances: Research Opportunities. Trust and Data Assurances in Capital Markets: The Role of Technology Solutions. Bryant College: 51-6.

Eurofiling (2011a): http://www.eurofiling.info/

Eurofiling (2011b): http//www.eurofiling.info/documents/CS-062_Data_Modelli ng.pdf

Fujitsu (2001): Fujitsu Interstage XWand. http///bit.ly/AbA8Hd

IIRC (2011): http///www.theiirc.org/

IFRS Foundation (2011): http://www.ifrs.org/Home.htm.

LYMER, A.; DEBRECENY, R. (2003): "The Auditor and Corporate Reporting on the Internet: Challenges and Institutional Responses", International Journal of Auditing, vol. 7: 103-120. http://dx.doi.org/10.1111/1099-1123.00063 
PLUMLEE, R.D.; PLUMLEE, M.A. (2008): "Assurance on XBRL for Financial Reporting", Accounting Horizons, vol. 22, n. 3: 353-368. http://dx.doi.org/10.2308/acch.2008.22.3.35

ROOHANI, S.; XIANMING, Z.; CAPOZZOLI, E.A.; LAMBERTON, B. (2010): "Analysis of XBRL Literature: A Decade of Progress and Puzzle", The International Journal of Digital Accounting Research, vol. 10: 131-147. http://dx.doi.org/10.4192/1577-8517-v10_6

SECURITIES \& EXCHANGE COMMISSION (2009): "Final rule: Interactive data to improve financial reporting", http://www.sec.gov/rules/final/2009/33-9002 SRIVASTAVA, R.P.; KOGAN, A. (2009): "Assurance on XBRL Instance Document: A Conceptual Framework of Assertions". http://ssrn.com/abstract=128 9467

VALENTINETTI, D.; REA, M. (2011): "Adopting XBRL in Italy: Early evidence of fit between Italian GAAP Taxonomy and current reporting practices of nonlisted companies", The International Journal of Digital Accounting Research, vol. 11: 45-67. http//dx.doi.org/10.4192/1577-8517-v11_3

XBRL (2011a): Dimensions. http://www.xbrl.org/Specification/XDT-REC-200609-18+Corrected-Errata-2009-09-07.htm.

XBRL (2011b): Formulae. http//www.xbrl.org/Specification/formula/REC-200906-22/formula-REC-2009-06-22.html

XBRL (2011c): iXBRL. http://www.xbrl.org/Specification/inlineXBRLpart1/REC-2010-04-20/inlineXBRL-part1-REC-2010-04-20+corrected-errata2011-08-17.html

XBRL (2011d): Table Linkbase. http//www.xbrl.org/WGN/table-Linkbaseoverview/PWD-2011-10-19/table-linkbase-overview-WGN-PWD-2011-1019.html

XBRL (2011e): "List of jurisdictions", XBRL.org. http://bit.ly/ay6cMt 


\section{ZCe Spanish Accounting and Business Administration Association INTEGRATED SCOREBOARD OF FINANCIAL, ENVIRONMENTAL, SOCIAL AND CORPORATE GOVERNANCE KEY PERFORMANCE INDICATORS (Public Working Draft as of 2012-03-31) ${ }^{3}$}

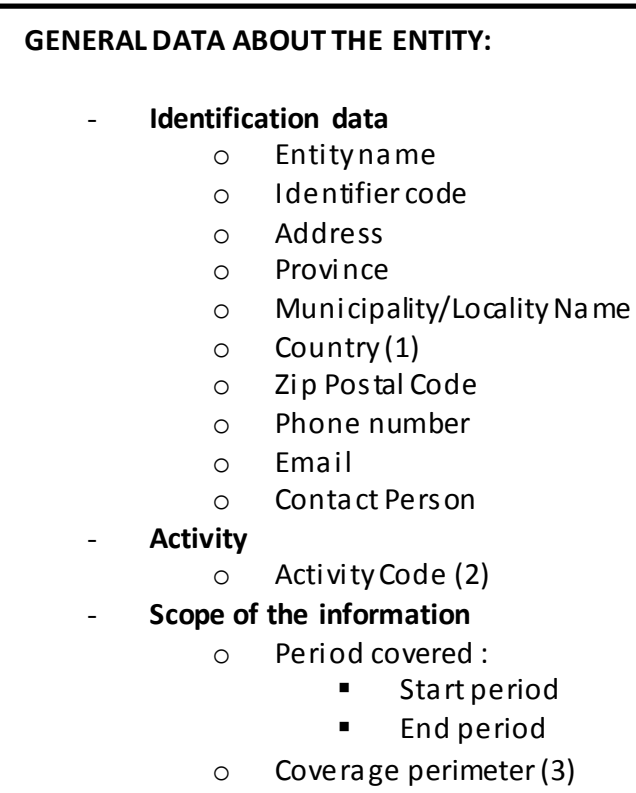

(1) Complete list of countries

(2) Several lists a vailable: i.e. NACE v2

(3) Indicate if the information is individual or in a consolidated basis, and the geographicals cope it covers.

\footnotetext{
${ }^{3}$ Additional indicators, alternative definitions and references, including ones to IFRSand IAS will be expected in the final public version.
} 


\section{FINANCIAL INDICATORS (11)}

\begin{tabular}{|c|c|c|c|c|}
\hline CODE & DENOMINATION & DEFINITION & PRESENTATION AND CONSIDERATIONS & REFERENCES \\
\hline \multicolumn{5}{|c|}{ Economic efficiency } \\
\hline KPI_F1 & Revenues & Total revenues of the year & \begin{tabular}{|l|} 
Presentation: \\
Addition of all revenues coming from sales and services provided, from financial and non- \\
financial investments and from selling intangible and tangible assets
\end{tabular} & EC1,1(UN) \\
\hline KPI_F2 & Suppliers & $\begin{array}{l}\text { Expenses related to } \\
\text { purchases and services }\end{array}$ & $\begin{array}{l}\text { Presentation: } \\
\text { Expenses related to purchase by suppliers and other operations } \\
\text { Considerations: } \\
\text { Includes acquisition of raw materials, components, fixed assets, installations, services } \\
\text { contracted, rents, licenses, taxes, royalties, freelance and sub-contracted workforce, } \\
\text { training expenses (when the training is provided by a third party), payments to external } \\
\text { capital providers, liabilities expenses (financial expenses), protection equipment for the } \\
\text { workforce, etc. }\end{array}$ & $\mathrm{EC} 1,4(\mathrm{UN})$ \\
\hline KPI_F3 & Added value & $\begin{array}{l}\text { Addition of outflows to all } \\
\text { stakeholders }\end{array}$ & \begin{tabular}{|l|} 
Presentation: \\
Distributed Economic Value \\
Considerations: \\
DEV is calculated adding: Employee compensation, suppliers' expenses, owner \\
retribution, Public Administration expenses and economic contribution to the community
\end{tabular} & EC1 (GRI) \\
\hline KPI_F4 & Employee benefits & $\begin{array}{l}\text { Expenses related to } \\
\text { employee compensation }\end{array}$ & $\begin{array}{l}\text { Presentation: } \\
\text { Employee expenses } \\
\text { Considerations: } \\
\text { Includes salaries and Social Security expenses }\end{array}$ & EC1, 6(UN) \\
\hline KPI_F5 & EBITDA & $\begin{array}{l}\text { Earnings Before Interest, } \\
\text { Taxes, Depreciation and } \\
\text { Amortization }\end{array}$ & $\begin{array}{l}\text { Addition of profit or loss after taxes, plus financial expenses, income taxes and } \\
\text { depreciation-amortization }\end{array}$ & \\
\hline KPI_F6 & Financial expense & Financial costs & \begin{tabular}{|l|} 
Presentation: \\
Expenses related to liabilities \\
Considerations: \\
Includes all interests and commissions to be paid to financial and non-financial \\
institutions
\end{tabular} & \\
\hline KPI_F7 & $\begin{array}{l}\text { Shareholders'/owners' } \\
\text { retribution }\end{array}$ & $\begin{array}{l}\text { Dividends to } \\
\text { owners/investors (Dividends }\end{array}$ & $\begin{array}{l}\text { Presentation: } \\
\text { Dividends and similar retribution to investors }\end{array}$ & EC1 \\
\hline
\end{tabular}


86 The International Journal of Digital Accounting Research

Vol. 12

\begin{tabular}{|c|c|c|c|c|}
\hline & & to all shareholders) & $\begin{array}{l}\text { Considerations: } \\
\text { Dividends and similar amounts whose distribution has been agreed during the year }\end{array}$ & \\
\hline KPI_F8 & $\begin{array}{l}\text { Public administration } \\
\text { expenses }\end{array}$ & Expenses related to taxes & $\begin{array}{l}\text { Presentation: } \\
\text { Taxes } \\
\text { Considerations: } \\
\text { Includes all the taxes, such as income taxes, taxes on properties, and to the different } \\
\text { administrations (local, regional, national and supra-national agencies) } \\
\end{array}$ & $\mathrm{EC1} 1,14(\mathrm{UN})$ \\
\hline KPI_F9 & $\begin{array}{l}\text { Economic contribution } \\
\text { to the community }\end{array}$ & $\begin{array}{l}\text { Donations and financial } \\
\text { help, of altruist character, } \\
\text { for the reported period }\end{array}$ & $\begin{array}{l}\text { Presentation: } \\
\text { Amount of contribution tothe community } \\
\text { Considerations: } \\
\text { Includes all kind of donations, directly or by means of any foundation }\end{array}$ & $\mathrm{EC1}, 15(\mathrm{UN})$ \\
\hline KPI_F10 & Result & $\begin{array}{l}\text { Profit or loss after taxes } \\
\text { divided by equity }\end{array}$ & \begin{tabular}{|l|} 
Presentation: \\
Profit or loss after taxes
\end{tabular} & \\
\hline KPI_F11 & Level of debt & $\begin{array}{l}\text { Level of debt at the end of } \\
\text { the year, divided by equity }\end{array}$ & $\begin{array}{l}\text { Presentation: } \\
\text { (Short term debt + Long term debt)/ Equity }\end{array}$ & \\
\hline
\end{tabular}


2. ENVIRONMENTAL INDICATORS (5)

\begin{tabular}{|c|c|c|c|c|}
\hline CODE & DENOMINATION & DEFINITION & PRESENTATION AND CONSIDERATIONS & REFERENCES \\
\hline \multicolumn{5}{|c|}{ Energy efficiency } \\
\hline KPI_E1 & Energy consumption & $\begin{array}{l}\text { Direct energy consumption in } \\
\text { gigajoules (GJ). }\end{array}$ & $\begin{array}{l}\text { Presentation: } \\
\text { GJ of energy consumption } \\
\text { Considerations: } \\
\text { Will include renewable + non-renewable energy consumption } \\
\text { See table of equivalences* }\end{array}$ & $\begin{array}{l}\text { EN3, } \\
\text { IC (UN) }\end{array}$ \\
\hline KPI_E2 & Water consumption & $\begin{array}{l}\text { Water consumption in cubic } \\
\text { meters }\left(\mathrm{m}^{3}\right)\end{array}$ & $\begin{array}{l}\text { Presentation: } \\
\text { Water consumption in cubic meters }\left(\mathrm{m}^{3}\right) \\
\text { Considerations: } \\
\text { The sum of all water drawn into the boundaries of the reporting organization from all } \\
\text { sources (including surface water, ground water, rainwater, and municipal water supply) for } \\
\text { any use over the course of the reporting period. }\end{array}$ & $\begin{array}{l}\text { EN8 (GRI), IA } \\
\text { (UN) }\end{array}$ \\
\hline KPI_E3 & Polluting emissions & $\begin{array}{l}\text { Greenhouse gases emissions, } \\
\text { directly deductible from energy } \\
\text { consumption }\end{array}$ & \begin{tabular}{|l|} 
Presentation: \\
Greenhouse gasses in $\mathrm{CO}_{2}$ equivalent tons \\
Considerations: \\
To transform energy consumption into $\mathrm{CO}_{2}$ emissions, the ECODES** framework will be \\
used
\end{tabular} & $\begin{array}{l}\text { EN16 (GRI) } \\
\text { IB (UN) }\end{array}$ \\
\hline \multicolumn{5}{|c|}{ Waste reduction } \\
\hline KPI_E4 & \begin{tabular}{|l} 
Waste \\
generation
\end{tabular} & $\begin{array}{l}\text { Waste generation, hazardous and } \\
\text { non-hazardous }\end{array}$ & $\begin{array}{l}\text { Presentation: } \\
\text { Waste generation in tons } \\
\text { Considerations: } \\
\text { Weight in tons of hazardous waste (as defined by national legislation at the point of } \\
\text { generation); and non-hazardous waste (all other forms of solid or liquid waste excluding } \\
\text { wastewater). }\end{array}$ & $\begin{array}{l}\text { EN22 (GRI) } \\
\text { IE (UN) }\end{array}$ \\
\hline KPI_E5 & Waste processed & $\begin{array}{l}\text { Waste processed, over total } \\
\text { residues generated }\end{array}$ & $\begin{array}{l}\text { Presentation: } \\
\text { Tons of waste processed } \\
\text { Considerations: } \\
\text { Processed waste is waste that has been re-used, recycled or re-valued. }\end{array}$ & $\begin{array}{l}\text { EN10, EN22 } \\
\text { (GRI) }\end{array}$ \\
\hline
\end{tabular}


3. SOCIAL INDICATORS (13)

\begin{tabular}{|c|c|c|c|c|}
\hline CODE & DENOMINATION & DEFINITION & PRESENTATION AND CONSIDERATIONS & REFERENCES \\
\hline \multicolumn{5}{|c|}{ Increase in Human Capital } \\
\hline KPI_S1 & Employees & $\begin{array}{l}\text { Employees with a labour } \\
\text { contract }\end{array}$ & $\begin{array}{l}\text { Presentation: } \\
\text { Number of employees with a contract at year end }\end{array}$ & $\begin{array}{c}\text { LA2 (GRI) } \\
5(\mathrm{NU})\end{array}$ \\
\hline KPI_S2 & Gender diversity of employees & $\begin{array}{l}\text { Women with a labour } \\
\text { contract }\end{array}$ & $\begin{array}{l}\text { Presentation: } \\
\text { Number of women with a contract at the yearend }\end{array}$ & LA2, LA13 (GRI) \\
\hline KPI_S3 & Gender diversity of top employees & $\begin{array}{l}\text { Women with a labour } \\
\text { contract, that have a } \\
\text { position in the top level }\end{array}$ & $\begin{array}{l}\text { Presentation: } \\
\text { Number of women at the top level of the entity } \\
\text { Considerations: } \\
\text { Management, such as the Management Board, the General } \\
\text { Direction and Deputy Directors are not included here. }\end{array}$ & \\
\hline KPI_S4 & Job stability & $\begin{array}{l}\text { Employees with a } \\
\text { permanent contract }\end{array}$ & $\begin{array}{l}\text { Presentation: } \\
\text { Number of employees with a permanent contract }\end{array}$ & $\begin{array}{c}\text { LA1 (GRI) } \\
5(\mathrm{NU})\end{array}$ \\
\hline KPI_S5 & Accidents and diseases at workplace & $\begin{array}{l}\text { Time ('days') that could not } \\
\text { be worked (and is thus 'lost') } \\
\text { as a consequence of a } \\
\text { worker or workers being } \\
\text { unable to perform their } \\
\text { usual work because of an } \\
\text { occupational accident or } \\
\text { disease. }\end{array}$ & $\begin{array}{l}\text { Presentation: } \\
\text { Number of lost days } \\
\text { Considerations: } \\
\text { Occupational accidents include those that take place in:(i) } \\
\text { workplaces; (ii) travel while working (iii) home/workplace travel. } \\
\text { A disease arising from the worksituation or activity (e.g., stress } \\
\text { or regular exposure to harmful chemicals), or from a work- } \\
\text { related injury. } \\
\text { Lost days are those that could not be worked (and are thus } \\
\text { 'lost') as a consequence of a worker or workers being unable to } \\
\text { perform their usual workbecause of an occupational accidentor } \\
\text { disease. }\end{array}$ & $\begin{array}{l}\text { LA7 (GRI) } \\
13(\mathrm{UN})\end{array}$ \\
\hline KPI_S6 & Absentee & $\begin{array}{l}\text { Lost days through non- } \\
\text { justifiable causes }\end{array}$ & $\begin{array}{l}\text { Presentation: } \\
\text { Number of days lost by a bsentee } \\
\text { Considerations: }\end{array}$ & LA7 (GRI) \\
\hline
\end{tabular}




\begin{tabular}{|l|l|l|l|l|}
\hline & & & $\begin{array}{l}\text { An employee absent from work for any reason that is not the } \\
\text { result of work-related injury or disease. } \\
\text { Permitted leave absences such as holidays, study, } \\
\text { maternity/paternity, and compassionate leave a re excluded. }\end{array}$ \\
\hline KPI_S7 & Employee turnover & $\begin{array}{l}\text { Employees who a bandon the } \\
\text { organization }\end{array}$ & $\begin{array}{l}\text { Presentation: } \\
\text { Total number of employees leaving employment during the } \\
\text { reporting period. } \\
\text { Considerations: } \\
\text { Employees wholeave the orga nization voluntarily or due to } \\
\text { dismissal, retirement, or death in service. All employees must be } \\
\text { includedin this calculation, regardless of contract type. }\end{array}$ \\
\hline KPI_S8 & Seniority & $\begin{array}{l}\text { Years of perma nence of } \\
\text { employees in the company }\end{array}$ & $\begin{array}{l}\text { Presentation: } \\
\text { Number of years of permanence of all employees }\end{array}$ \\
\hline KPI_S9 & Employee training & $\begin{array}{l}\text { Presentation: } \\
\text { Number of training hours for the year } \\
\text { Considerations: } \\
\text { Refers to all kind of professional training and education, } \\
\text { provided internally or externally (ifit is paid totally } \\
\text { by the entity). Does not include regular training provided during } \\
\text { work by supervisors. }\end{array}$ \\
\hline Increase in Social Capital & $\begin{array}{l}\text { Training received bythe } \\
\text { employees }\end{array}$ & $\begin{array}{l}\text { LA10 (GRI) } \\
\text { (UN) }\end{array}$ \\
\hline
\end{tabular}


90 The International Journal of Digital Accounting Research

Vol. 12

\begin{tabular}{|c|c|c|c|c|}
\hline KPI_S10 & $\begin{array}{l}\text { Non-compliance with legal } \\
\text { regulation concerning } \\
\text { customers }\end{array}$ & $\begin{array}{l}\text { Number of incidents of non- } \\
\text { compliance with regulation } \\
\text { concerning customers }\end{array}$ & \begin{tabular}{|l|} 
Presentation: \\
Incidents of non-compliance with regulations resulting in a fine \\
penalty. \\
Considerations: \\
Incident is any complaint or claim which has a resolution by the \\
competent authority (administrative, arbitration or judicial), \\
although this resolution could be appealed by the organization. \\
As issues related to customers, the following will be considered: \\
impacts of products a nd services on health and safety during \\
their life-cycle, information and labelling of products and \\
services, marketing communications, advertising, promotionand \\
sponsorship, privacy and lea kage of personal data of customers.
\end{tabular} & PR2 (GRI) \\
\hline KPI_S11 & Locally-based suppliers & $\begin{array}{l}\text { Locally-based suppliers of } \\
\text { the company }\end{array}$ & $\begin{array}{l}\text { Presentation: } \\
\text { Number of locally-based suppliers } \\
\text { Considerations: } \\
\text { Locally-based suppliers are those that operate in a concrete } \\
\text { geographical space, such as the nation, region or local ity where } \\
\text { the entity also operates. }\end{array}$ & $\begin{array}{l}4(\mathrm{UN}) \\
\text { EC } 6 \text { (GRI) }\end{array}$ \\
\hline KPI_S12 & CSR certified suppliers & $\begin{array}{l}\text { Percentage of suppliers who } \\
\text { present a certification on } \\
\text { corporate social } \\
\text { responsibility }\end{array}$ & $\begin{array}{l}\text { Presentation: } \\
\text { Number of CSR certified suppliers } \\
\text { Considerations: } \\
\text { A strategic supplier is according to the entity perception of } \\
\text { transaction volume. } \\
\text { Some CSR certifications are: ISO14001/EMAS, SA8000, OHSAS, } \\
\text { FQM, SG21, RS10:2009. }\end{array}$ & \\
\hline KPI_S13 & Payment period to suppliers & $\begin{array}{l}\text { Average invoices payment } \\
\text { period }\end{array}$ & $\begin{array}{l}\text { Presentation: } \\
\text { Average number of days between invoice dates and payment } \\
\text { dates }\end{array}$ & \\
\hline
\end{tabular}


4. CORPORATE GOVERNANCE INDICATORS (8)

\begin{tabular}{|c|c|c|c|c|}
\hline CODE & DENOMINATION & DEFINITION & PRESENTATION AND CONSIDERATIONS & REFERENCES \\
\hline \multicolumn{5}{|c|}{ Fair corporate governance } \\
\hline KPI_CG1 & Board members & $\begin{array}{l}\text { Number of board } \\
\text { members }\end{array}$ & \begin{tabular}{|l|} 
Presentation: \\
Number of Board members
\end{tabular} & CSR-AECA $^{4}$ \\
\hline KPI_CG2 & $\begin{array}{l}\text { Independent board } \\
\text { members }\end{array}$ & $\begin{array}{l}\text { Number of independent } \\
\text { board members }\end{array}$ & $\begin{array}{l}\text { Presentation: } \\
\text { Number of independent board members } \\
\text { Considerations: } \\
\text { State how the organization defines 'independent' and } \\
\text { 'non-executive'. This element applies only for } \\
\text { organizations that have unitary board structures }\end{array}$ & $\begin{array}{l}4.3(\text { GRI 3.1) } \\
\text { CSR-AECA }\end{array}$ \\
\hline KPI_CG3 & Executive Committee & $\begin{array}{l}\text { Number of members of } \\
\text { Executive Committee }\end{array}$ & $\begin{array}{l}\text { Presentation: } \\
\text { Number of members of the Committee that sets the } \\
\text { company's strategy }\end{array}$ & \\
\hline KPI_CG4 & Audit Committee & $\begin{array}{l}\text { Number of members of } \\
\text { Audit Committee }\end{array}$ & $\begin{array}{l}\text { Presentation: } \\
\text { The Audit Committee is responsible for controlling } \\
\text { and monitoring of external and internal auditors }\end{array}$ & \\
\hline KPI_CG5 & Nominations Committee & $\begin{array}{l}\text { Number of members of } \\
\text { Nominations Committee }\end{array}$ & $\begin{array}{l}\text { Presentation: } \\
\text { Number of Nominations Committee members }\end{array}$ & \\
\hline KPI_CG6 & Meetings of the Board & $\begin{array}{l}\text { Number of meetings of } \\
\text { the Board }\end{array}$ & $\begin{array}{l}\text { Presentation: } \\
\text { Number of meetings held by the Board annually }\end{array}$ & \\
\hline KPI_CG7 & $\begin{array}{l}\text { Total remuneration of } \\
\text { the Board }\end{array}$ & $\begin{array}{l}\text { Board remuneration } \\
\text { costs }\end{array}$ & $\begin{array}{l}\text { Presentation: } \\
\text { Remuneration paid to board members }\end{array}$ & CSR-AECA \\
\hline KPI_CG8 & $\begin{array}{l}\text { Gender diversity on } \\
\text { Management Board }\end{array}$ & $\begin{array}{l}\text { Women with a labour } \\
\text { contract, that have a } \\
\text { position in the } \\
\text { Management }\end{array}$ & $\begin{array}{l}\text { Presentation: } \\
\text { Number of women at the Management level } \\
\text { Considerations: } \\
\text { Management, such as the Management Board, the } \\
\text { General Direction and Deputy Directors are included } \\
\text { here. }\end{array}$ & LA13 (GRI) \\
\hline
\end{tabular}

References in this Appendix: United Nations (UN), Global Reporting Initiative (GRI), and previous CSR projects of AECA.

${ }^{4}$ CSR-AECA is the Corporate Social Responsibility Framework of the Spanish Accounting and Business Administration Association (AECA), available at www.aecareporting.com 